\title{
SUSTAINABLE DEVELOPMENT GOALS AGAINST COVID-19:THE PERFORMANCE OF BRAZILIAN CITIES IN SDGS 3 AND 6 AND THEIR REFLECTION ON THE PANDEMIC
}

\author{
Felipe R. da Silva ${ }^{1 *}$, Samuel F. Câmara', Francisco R. Pinto', Marcelo Soares², \\ Michael B. Viana ${ }^{2}$, Thiago M. De Paula' \\ 'Universidade Estadual do Ceará - BlueLab - PPGA, Fortaleza, Ceará, Brazil \\ ¿Universidade Federal do Ceará, Fortaleza, Ceará, Brazil \\ *Corresponding author: felipe.roberto@aluno.uece.br \\ Received: November 28 ${ }^{\text {th }}, 2020$ / Accepted: February 16 ${ }^{\text {th }}, 2021$ / Published: April $1^{\text {st }}, 2021$ \\ https://DOl-10.24057/2071-9388-2020-188
}

\begin{abstract}
The aim of this article is to understand the relationship between two of the Sustainable Development Goals (UN Agenda 2030) - Good health and well-being (SDG 3) and Clean water and sanitation (SDG 6) - and the statistics of the COVID-19 pandemic (number of cases and deaths) in Brazilian cities. To analyze this relationship, we used secondary data from public organizations on the SDG panorama by city and conducted a moderated regression analysis. The sample was composed of 649 cities with a population exceeding 50 thousand inhabitants. The results show that the higher were the indicators used to measure SDGs, the lower was the number of cases and deaths from the disease. We have also proved that cities' population density and their distance from the pandemic epicenter moderate this relationship, since a higher level of these moderation variables increases the impact of a lower level of SDGs 3 and 6 coverage in society on the number of cases and deaths from COVID-19. Thus, the efficient and effective investment to reach SDGs 3 and 6 is directly associated with cities' ability to successfully deal with infectious diseases and the resulting number of deaths. As for its contribution, this research innovates by establishing a model for analyzing the impact of compliance with SDGs on cities' performance in their fight against COVID-19, which may also suit other nations.
\end{abstract}

KEY WORDS: Environmental Development; Coronavirus; Pandemic Outbreak; Sustainability

CITATION: Felipe R. da Silva, Samuel F. Câmara, Francisco R. Pinto, Marcelo Soares, Michael B. Viana, Thiago M. De Paula (2021). Sustainable Development Goals Against Covid-19: The Performance Of Brazilian Cities In Sdgs 3 And 6 And Their Reflection On The Pandemic. Geography, Environment, Sustainability, Vol.14, No 1, p. 9-16 https://DOl-10.24057/2071-9388-2020-188

ACKNOWLEDGMENTS: M. O. Soares thanks the Conselho Nacional de Desenvolvimento Científico e Tecnológico - CNPq (Research Productivity Fellowship, 307061/2017, 310165/2020-2 and 313518/2020-3), PELD Costa Semiárida do Brasil (442337/2020-5), CAPES-PRINT, and the Fundação Cearense de Apoio ao Desenvolvimento Científico e Tecnológico (Chief Scientist Program) for financial support. And F. R. Silva thanks the Instituto, Desenvolvimento, Estratégia e Conhecimento (IDESCO) for the technical support and dissemination of the study.

Conflict of interests: The authors reported no potential conflict of interest.

\section{INTRODUCTION}

COVID-19 pandemic and its effects on achieving SDGs

The world is facing one of the most serious moments in its history with the advance of SARS-CoV-2, a virus that triggers a severe acute respiratory syndrome called COVID-19, which has killed more than 2,700,000 people worldwide (Johns Hopkins University [JHU]' 2020; Jurcik et al. 2020). The impact of this disease goes beyond the health sphere, also triggering social, economic, cultural and environmental problems (Chakraborty and Maity 2020; Shakil et al. 2020;Zambrano-Monserrate, Ruano and Sanchez-Alcalde 2020; Sarkar, Debnath and Reang 2020). Therefore, its effects pose a serious threat to the development prospects of nations (Khetrapal and Bhatia 2020; Leal Filho et al. 2020). One of the major challenges for countries, especially the developing ones, is to comply with the Sustainable Development Goals (SDGs) since their financial, political and technological resources have been directed to contain the pandemic (Khetrapal and Bhatia 2020).

The 17 SDGs were established by the United Nations Agenda 2030 plan of action on September 25, 2015, and became effective in January 2016. All developed and developing countries must promote and implement these

'Johns Hopkins University [JHU] (2020). COVID-19 Dashboard by the Center for Systems Science and Engineering (CSSE). Available at: https://www.arcgis.com/apps/opsdashboard/index.htm/\#/bda7594740fd40299423467b48e9ecf6 [Accessed 25 Set. 2020] 2 United Nations [UN] (2015). Transforming our world: the 2030 Agenda for sustainable development. Available at: https:// sustainabledevelopment.un.org/post2015/transformingourworld [Accessed 7 Set. 2020]. 
global goals as mediators for building practical tools to respond to systemic and universal problems, among them water management and sanitation, as well as global health care (United Nations [UN]22 2015; Mordeson and Mathew 2020; Delanka-Pedige et al. 2020).

Many of these objectives are interconnected, which has led to an increased impact of the COVID-19 pandemic on all of them (Huan, Liang and Zhang 2020; Zhao et al. 2020). However, some studies (Ahmed et al. 2020; Khetrapal and Bhatia 2020) have called attention to two specific problems associated with the disease: the first detections of SARSCoV-2 in untreated residual waters, and the effects of the disease on the health and well-being of populations around the world. These are indications that non-compliance with SDG 3 (health and well-being) and SDG 6 (clean water and sanitation) affects cities' performance in responding to a pandemic such as COVID-19. In addition, few studies (Khetrapal and Bhatia 2020; Mordeson and Mathew 2020; Leal Filho et al. 2020; Iwuoha and Jude-Iwuoha 2020) took into account the association between SDGs and COVID-19, although they did not intend to develop models that associate SDG results with COVID-19 statistics (cases and deaths from the disease). It is important to point out that the achievement of these sustainable objectives is reached through the adoption of indicators and monitoring tools, which are often used in literature (e.g. Bobylev et al. 2018; Kristjánsdóttir, Ólafsdóttir and Ragnarsdótti, 2018), since they allow to simplify, aggregate and clarify the information available to policymakers. In addition, the indicators are understood as means and not ends to achieve sustainable development, so the cross-analysis of the indexes can provide more accurate results (MacDonald et al. 2018).

The pandemic duration is uncertain, and nobody can estimate its full effects yet; therefore, the achievement of goals for each SDG within the given period (up to 2030, at most) becomes more and more difficult (Khetrapal and Bhatia 2020). Hence, we draw attention to developing countries, since some studies (Ahmed et al. 2020) show that COVID-19 affects them more negatively. One of these countries, Brazil, has unique environmental, social, and economic characteristics, such as high social inequality, deficiencies in public health, high and constant air and water temperatures, low rates of basic sanitation and high population density among the states (Von Braun, Zamagni and Sorondo 2020; Hart and Halden 2020). Therefore, these social, political, economic and environmental gaps between cities, states and regions can worsen the pandemic effects (Rourke et al. 2020; Khetrapal and Bhatia 2020) as well as make it impossible to meet these sustainable goals, especially SDGs 3 and 6.

In addition, on 03/18/2021, Brazil was the second country in the number of cases, and second - in the number of deaths from COVID-19 (JHU 2020), and this virus has spread to several regions in the country, from the North (the Amazon) to the South, close to Argentina and Uruguay (Candido et al. 2020). Hence, this study aims to understand the relationship between these two Sustainable Development Goals - Good health and wellbeing (SDG 3), and Clean water and sanitation (SDG 6) - and the distribution of COVID-19 cases and deaths in Brazilian cities.

\section{SDG 3 (Good health and well-being) and COVID-19}

SDG 3 aims at the well-being of individuals and the collective health of all communities (UN 2015). This objective promotes restructuring of the health system, thus strengthening the proposal of universal coverage (Seidman
2017). Therefore, this SDG is associated with the current pandemic the most as the first effects of non-compliance with it will directly affect the health system (Leal Filho et al. 2020).

COVID-19 continues to harm public health and its effects may be worse in tropical and subtropical countries like Brazil, which fights a battle against endemics such as dengue, malaria and yellow fever (Zeng et al. 2018). In addition, most developing countries suffer from the ineffectiveness of the health system due to the lack of funding, equipment, qualified personnel and poor hospitals' infrastructure, which mainly affects the most vulnerable communities from the social and economic standpoint (Leal Filho et al. 2020; Von Braun, Zamagni, and Sorondo 2020).

Previous studies (Kruk et al. 2018; Lucas et al. 2019) assessed the impact of achieving SDGs on countries' mortality rates, showing that countries with better SDG indices also demonstrate better cost-benefit ratios in the health system. Wang et al. (2020) associated population density with cases and deaths from COVID-19, and Câmara, Pinto, Silva and Gerhard (2020) showed that the distance from the epicenter is related to the growth of the virus proliferation curve. Therefore, considering the current scenario - a global health crisis caused by the COVID-19 pandemic - we have developed the following hypotheses:

$H_{1}$ - Cities that do not comply with SDG 3 report a higher number of COVID-19 cases;

$\mathrm{H}_{2}$ - Cities that do not comply with SDG 3 report a higher number of deaths from COVID-19;

$\mathrm{H}_{3}$ - Population density moderates the relationship between SDG 3 and the number of COVID-19 cases;

$\mathrm{H}_{4}$ - Population density moderates the relationship between SDG 3 and the number of deaths from COVID-19;

$\mathrm{H}_{5}$ - The distance between cities and the epicenter of the pandemic moderates the relationship between SDG 3 and the number of COVID-19 cases.

\section{SDG 6 (Clean water and sanitation) and COVID-19}

SDG 6 deals with sustainable water management and the quality of sewage services. Water is a critical component for life and human development, thus, it is vital in the battle against this pandemic (UN 2020) ${ }^{1}$.

There is a consensus that the main transmission route of COVID-19 is close contact with infected people by either handshake, saliva droplets, sneeze, cough or vomit (Dehning et al. 2020). Therefore, the hygiene of the environment and body, especially hands, is essential to avoid COVID-19 transmission (Azoulay and Jones 2020). However, basic sanitation conditions in several regions of developing countries are still very precarious, which brings risks of secondary transmission. Another problem associated with the lack or discontinuity of clean water supply is that people end up resorting to alternative solutions for access to water, that is, access to sources such as lakes, ponds and rivers contaminated with other biological and chemical pathogens. These solutions are not the most appropriate as people may be infected by SARS-CoV-2 (Rimoldi et al. 2020) in addition to becoming susceptible to other transmission routes, such as fecal-oral.

Fecal-oral transmission of a disease concerns any form of contagion where the disease's etiologic agent is expelled through the host's feces or urine and is transmitted to a potential host either by direct ingestion, aerosols of contaminated water or by fomites associated with the action of biological vectors (Ahmadiara 2020). Up to now, there is no scientific evidence of fecal-oral transmission of 
COVID-19, but it cannot be ruled out since this has occurred with other viruses of the coronavirus family. Several studies have found the presence of the SARS-CoV-2 virus in the feces and urine of symptomatic and non-symptomatic people throughout the world (W. Ahmed et al. 2020; Kitajima et al. 2020).

Hence, cities with worse conditions of sanitary sewage and water distribution can facilitate virus proliferation, and SDG 6 sets these conditions (Azoulay and Jones 2020; Kitajima et al. 2020). Furthermore, population density and distance from the epicenter can be decisive in this relationship (Câmara et al. 2020; Wang et al. 2020). A city with a high number of individuals requires an efficient water supply and sanitary sewage for everyone (Delanka-Pedige et al. 2020). Likewise, the closer to the epicenter, the greater is the risk that a certain natural resource is contaminated due to virus proliferation. Therefore, we propose additional hypotheses:
$\mathrm{H}_{6}$ - Cities that do not comply with SDG 6 report a higher number of COVID-19 cases;

$\mathrm{H}_{7}$ - Cities that do not comply with SDG 6 report a higher number of deaths from COVID-19;

$\mathrm{H}_{8}$ - Population density moderates the relationship between SDG 6 and the number of COVID-19 cases;

$\mathrm{H}_{0}$ - Population density moderates the relationship between SDG 6 and the number of deaths from COVID-19;

$\mathrm{H}_{10}$ - The distance between cities and the epicenter of the pandemic moderates the relationship between SDG 6 and the number of COVID-19 cases.

\section{METHODOLOGY}

To achieve the research objective, we carried out a quantitative study based on secondary data in 649 Brazilian cities with more

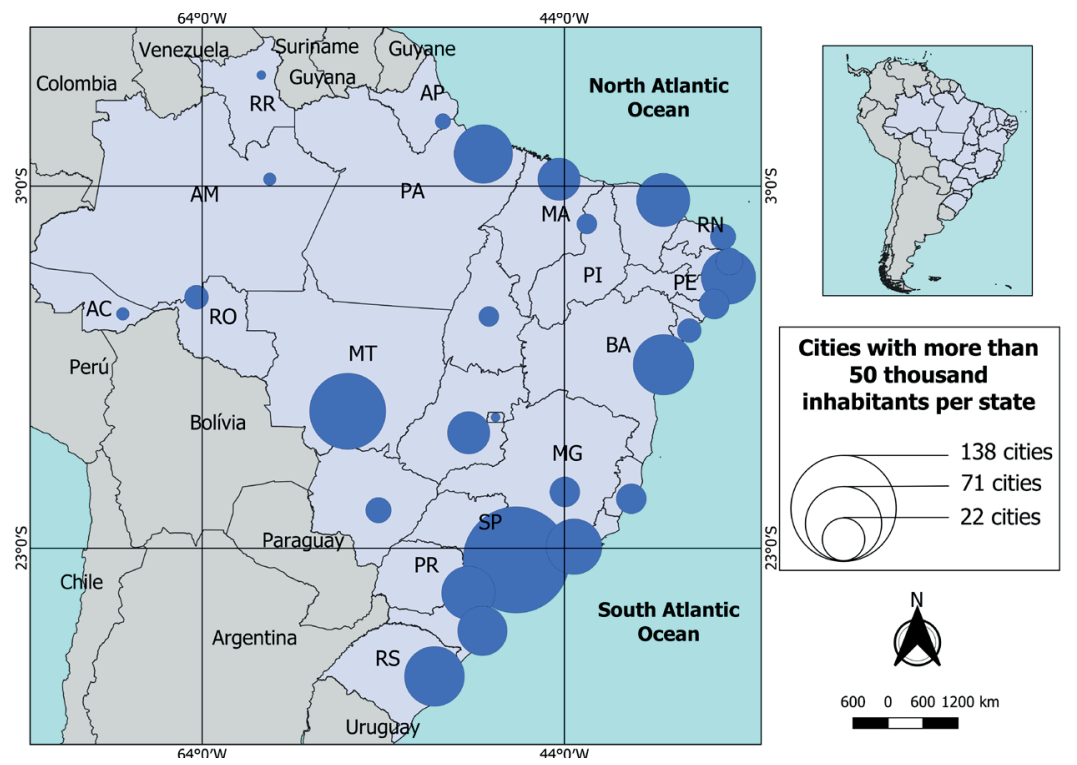

Fig. 1. Number of Brazilian cities with population over 50 thousand inhabitants, per State. $A C=A c r e ; A L=A l a g o a s ; A P=$ Amapá; $\mathrm{AM}=$ Amazonas; BA = Bahia; CE = Ceará; DF = Distrito Federal; ES = Espírito Santo; GO = Goiás; MA = Maranhão; MT = Mato Grosso; MS = Mato Grosso do Sul; MG = Minas Gerais; PA = Pará; PB = Paraíba; PR = Paraná; PE = Pernambuco; PI = Piauí; RJ = Rio de Janeiro; RN = Rio Grande do Norte; RS = Rio Grande do Sul; RO = Rondônia; RR = Roraima; SC = Santa Catarina; SP = São Paulo; $\mathrm{SE}=$ Sergipe; TO = Tocantins.

Note. Made with software Qgis version 3.4.13.

Table 1. Description of the variables analyzed for each SDG and the organizations that provided them

\begin{tabular}{|c|c|c|}
\hline Objective & Organization & Data collected from the cities \\
\hline SDG 3 & $\begin{array}{l}\text { Informatics Department of Unified Health System } \\
\text { (DATASUS) }\end{array}$ & $\begin{array}{l}\text { Number of neonatal deaths } \\
\text { Number of child deaths (up to } 5 \text { years old) } \\
\text { Number of deaths } \\
\text { Maternal deaths during pregnancy or up to } 42 \text { days after giving birth } \\
\text { Number of live births of women aged } 15 \text { to } 19 \text { years old } \\
\text { Number of new HIV cases } \\
\text { Number of malaria cases } \\
\text { Number of hepatitis B cases } \\
\text { Number of deaths by suicide } \\
\text { Number of deaths by traffic accidents } \\
\text { Vaccination coverage } \\
\text { Abandonment of vaccination }\end{array}$ \\
\hline SDG 6 & $\begin{array}{c}\text { National Information System on Sanitation (SNIS) } \\
\text { and Trata Brasil Institute }\end{array}$ & $\begin{array}{l}\text { Level of coverage of the urban and rural population by water supply } \\
\text { Level of coverage of the urban population by piped water } \\
\text { Level of coverage the of urban and rural population by sewage collection } \\
\text { The volume of treated sewage in relation to the volume of water consumed, } \\
\text { controlled by the collection rates }\end{array}$ \\
\hline
\end{tabular}

'Instituto Brasileiro de Geografia e Estatística [IBGE]. (2015). Pesquisa Nacional por Amostra de Domicílios (PNAD). Available at: https://Www. ibge.gov.br/estatisticas/sociais/populacao/9127-pesquisa-nacional-por-amostra-de-domicilios.html?=\&t=0-que-e [Accessed 15 Set. 2020]. ${ }^{2}$ Governo do Estado de São Paulo (SP) (2019). 10 Relatório de Acompanhamento dos Objetivos de Desenvolvimento Sustentável do Estado de São Paulo. São Paulo, Brasil. Available at: http://WwW.seade.gov.br/wpcontent/uploads/2019/07/SDGsp.pdf [Accessed 20 Set. 2020]. 
than 50 thousand inhabitants (Fig. 1) according to the last census conducted by the Brazilian Institute of Geography and Statistics $(\text { (IBGE) })^{1}$ in 2010. We used this population limit and this sample size $(n=649)$ because databases did not have enough information for cities with a population below 50 thousand inhabitants.

We defined the criterion for selecting the variables according to the State of São Paulo monitoring report on SDGs (SP 2019)², based on the goals established by Agenda 2030 for each objective (UN 2015). Thus, we divided the data analysis into two stages. First, we measured an index for each SDG from the collected information. In SDG 3, where the variables are represented in gross values, the indices were placed in the order from worse to better performance of the cities in the respective ODS variable. Subsequently, the sample was divided into percentiles, that is, it was placed in each class interval $1 \%$ of the series elements. Regarding the time frame, the period 2010-2018 was considered for the analysis considered.

As for SDG 6, we adopted the methodology developed by Trata Brasil Institute (2020)', which considers the total coverage level for water supply when the service rates reach 100\%, while for sewage collection it considers total coverage as $98 \%$ of service. To calculate the level of water and sewage coverage, we used the following equations, established by SNIS (2018)².

Where:

$$
I A=\frac{P O P w a t e r}{P O P}
$$

$I A=$ Total water service rate or urban water service rate;

POPwater $=$ Total population served with water or urban population served with water;

$P O P=$ Total population or urban population .

Where:

$$
I E=\frac{\text { POPsewage }}{P O P}
$$

$I E=$ Total sewage service rate or urban sewage service rate;

POPsewage $=$ Total population served with sewage or urban population served with sewage;

$P O P=$ Total population or urban population.
Where:

$$
I E A C=\frac{V E}{(V a c-V a e)}
$$

IEAC $=$ Treated sewage rate by water consumed;

$V e=$ Volume of treated sewage;

$V a c=$ Volume of water consumed;

Vae $=$ Volume of water exported.

Thus, once we measured the indices, we adopted the weighted mean for the final composition of SDG 6, where the indices in equations 1, 2 and 3 added up to 10\%, 20\% and $40 \%$ of the grade, respectively (Trata Brasil 2020). Finally, we calculated the dependent variables (DV) from the relationship between the COVID-19 statistics (number of cases and deaths) and the city's total population. These dependent variables were considered one at a time because the number of cases of the disease is not reflected in the same proportion as the number of deaths. Furthermore, the data referring to the COVID-19 statistics and the city's total population were extracted from DATASUS (2020c) $)^{3}$ and IBGE $(2020)^{4}$, respectively.

For the second stage of the research, in which the relationships proposed by the hypotheses was investigated, we used the techniques of multivariate data analysis from moderation processes (Model 1) with the aid of PROCESS (Hayes 2013) ${ }^{5}$ - Statistical Package for the Social Sciences (SPSS) software, version 24.0. In addition, we tested the proposed moderators by using a bootstrapping test with 10,000 samples.

We carried out preliminary data analyses to check the normality and presence of multicollinearity among the variables. As the calculations of the number of cases and deaths over the total population showed high asymmetry and kurtosis, we made logarithmic changes in these variables. Next, to check the presence of multicollinearity, we conducted Pearson's correlation analysis to identify the level of association among the variables (Tabachnick and Fidell 2001) ${ }^{6}$. Finally, in order to identify outliers, we used the multivariate detection through the Mahalanobis measure, excluding the cities of Viçosa-MG, Guanambi-BA and Palmas-PR for the statistical analyses with the variable «deaths from COVID-19», where, at the time, there were no records of

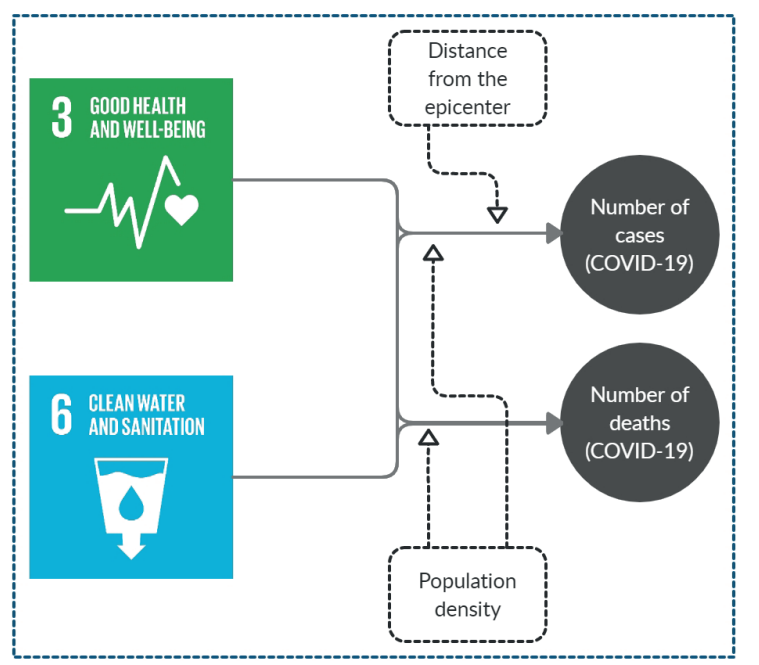

Fig. 2. Proposed conceptual model of the research hypotheses

1 Instituto Trata Brasil (2020). Ranking do saneamento. São Paulo, Brasil. Available at: http://tratabrasil.org.br/images/estudos/itb/ranking_2020/ Relatorio_Ranking_Trata_Brasil_2020_Julho_.pdf [Accessed 3 Set. 2020]

2 Sistema Nacional de Informações sobre Saneamento [SNIS]. (2018). SNIS: série histórica. Available at: http://app4.mdr.gov.br/serieHistorica/\# [Accessed 16 Set. 2020].

${ }^{3}$ Sistema de Informática do Sistema Único de Saúde [DATASUS]. (2020c). Painel Coronavírus. Available at: https://covid.saude.gov.br/ [Accessed 14 Set. 2020].

${ }^{4}$ Instituto Brasileiro de Geografia e Estatística [IBGE]. (2020). IBGE Cidades. Available at: https://cidades.ibge.gov.br/ [Accessed 8 Set. 2020].

${ }^{5}$ Hayes, A. F. (2013). Model templates for SPSS and SAS. Behavior Research Methods, Instruments, \& Computers, 36, 717-731. ISBN 978-1-60918-230-4

${ }^{6}$ Tabachnick, B. G. and Fidell, L. S. Using multivariate statistics (4th ed.) Needham Heights, MA.: Allyn and Bacon.

${ }^{7}$ Hayes, A. F. (2017). Introduction to mediation, moderation, and conditional process analysis: A regression-based approach. New York: Guilford. 
deaths from the disease. Thus, at the end of this stage, the sample had 646 valid observations. We found no outliers for the variable «COVID-19 cases».

Furthermore, we standardized all the variables in order to compare scales with different metrics, since such a procedure does not lead to distortions in variables' interactions (Hayes 2017) ${ }^{7}$. Figure 2 presents the proposed theoretical model based on the hypotheses.

\section{RESULTS}

Descriptive statistics and the correlation matrix of all study variables showed that the numbers of cases and deaths from COVID-19 were positively related to the levels of non-compliance with SDGs 3 and 6 (Table 2). However, as these correlation coefficients were not extremely high, there was no multicollinearity among the variables (Tabachnick and Fidell 2001). The correlation matrix provides a significant initial analysis of the association of variables. From this, more robust analysis models were designed to verify these associations.
As for the hypotheses testing, the results of the moderation analysis of the effect of a city's population distance and its density on the relationship between SDG and the COVID-19 levels over the population indicate a certain relationship (Table 3). For the relationship between SDG and COVID-19, the results show a significant negative direct effect of SDG $3(\beta=-5.30 ; p<0.000)$ and SDG $6(\beta=-5.04 ; p<0.000)$ variables on the number of cases. Therefore, hypotheses $\mathrm{H}_{1}$ and $\mathrm{H}_{6}$ were confirmed.

Regarding the effects of the first moderation, we noticed that population density regulates the relationship between SDGs and COVID-19 cases, showing a statistically significant negative effect of SDG $3(\beta=-2.35 ; p<0.05)$ and SDG 6 $(\beta=-3.44 ; p<0.000)$ on the disease cases. Thus, we can infer that the impact of these goals on the number of COVID-19 cases gets higher with increasing population density in the city (Table 3).

Likewise, the combined effect of cities' distance with that of SDG $3(\beta=-1.99 ; p<0.05)$ and SDG $6(\beta=-3.40 ; p<0.000)$ was negatively significant, showing that the impact of SDGs on the COVID-19 cases is weaker for cities that are further away from the pandemic's initial dissemination zones. In addition, the graphical representation of moderation, in Table 3, shows that distance was a natural sociogeographical obstacle for the disease spread despite the low levels of SDG. Therefore, hypotheses $\mathrm{H}_{3^{\prime}} \mathrm{H}_{5^{\prime}} \mathrm{H}_{8}$ and $\mathrm{H}_{10}$ were accepted.

Table 2. Correlation of variables, mean and standard deviation for variables 1 to 6 for Brazilian cities

\begin{tabular}{|c|c|c|c|c|c|c|c|c|}
\hline Variables & Mean & S.D. & 1 & 2 & 3 & 4 & 5 & 6 \\
\hline 1. Cases/Population & .013 & .009 & 1.00 & & & & \\
\hline 2.Deaths/Population & .0003 & .000 & $.549^{* * *}$ & 1.00 & & & \\
\hline 3. SDG 3 & 50.16 & 21.2 & $-.158^{* * *}$ & $-.301^{* * *}$ & 1.00 & & & \\
\hline 4. SDG 6 & .5309 & .299 & $-.187^{* * *}$ & $-.192^{* * *}$ & $-.197^{* * *}$ & 1.00 & & \\
\hline 5. Distance & 235.6 & 229 & $.065^{*}$ & $-.232^{* * *}$ & $.085^{* *}$ & $-.086^{* *}$ & 1.00 & \\
\hline 6. Density & 652.6 & 1567 & -.003 & $.312^{* * *}$ & $-.370^{* * *}$ & $-.155^{* * *}$ & $-.284^{* *}$ & 1.00 \\
\hline
\end{tabular}

Note. ${ }^{*} p<0.1 ;{ }^{* *} p<0.05 ;{ }^{* * *} p<0.01$

Table 3. Moderation Analysis for the number of COVID-19 cases in the population

\begin{tabular}{|c|c|c|c|c|c|c|c|}
\hline \multicolumn{8}{|c|}{ COVID-19 cases/population } \\
\hline Structural path & $\beta$ & SE & $R^{2}$ & Structural path & $\beta$ & SE & $R^{2}$ \\
\hline \multicolumn{4}{|c|}{$(F=10.1191 ; 3 ; 642 ; p<0.000)$} & \multicolumn{4}{|c|}{$(F=14.0284 ; 3 ; 642 ; p<0.000)$} \\
\hline Constant & $0.048(1.161)$ & & & Constant & $-0.031(-0.782)$ & & \\
\hline SDG 3 & $-0.224\left(-5.30^{* * *}\right)$ & 0.042 & & SDG 6 & $-0.201\left(-5.04^{* * *}\right)$ & 0.040 & \\
\hline Density & $0.036(0.868)$ & 0.042 & & Density & $-0.104\left(-2.63^{* * *}\right)$ & 0.399 & \\
\hline SDG 3x Density & $-0.095\left(-2.35^{* *}\right)$ & 0.040 & .045 & SDG 6 x Density & $-0.138\left(-3.44^{* * *}\right)$ & 0.040 & 0.061 \\
\hline \multicolumn{4}{|c|}{$(F=9.231 ; 3 ; 642 ; p<0.000)$} & \multicolumn{4}{|c|}{$(F=13.4605 ; 3 ; 642 ; p<0.000)$} \\
\hline Constant & $0.027(0.689)$ & & & Constant & $-0.005(0.136)$ & & \\
\hline SDG 3 & $-0.193\left(-4.83^{* * *}\right)$ & 0.040 & & SDG 6 & $-0.167\left(-4.43^{* * *}\right)$ & 0.038 & \\
\hline Distance & $-0.057(-1.392)$ & 0.041 & & Distance & $-0.096\left(-2.51^{* * *}\right)$ & 0.038 & \\
\hline SDG $3 \times$ Distance & $-0.075\left(-1.99^{* *}\right)$ & 0.037 & 0.041 & SDG $6 \times$ Distance & $-0.129\left(-3.40^{* * *}\right)$ & 0.038 & 0.059 \\
\hline
\end{tabular}

Note. ${ }^{* *}$ Significant at 5\%; *** Significant at 1\%.

Table 4. Moderation Analysis for the number of deaths in the population

\begin{tabular}{|c|c|c|c|c|c|c|c|}
\hline \multicolumn{8}{|c|}{ COVID-19 deaths/population } \\
\hline Structural path & $\beta$ & SE & $R^{2}$ & Structural path & $\beta$ & SE & $R^{2}$ \\
\hline \multicolumn{4}{|c|}{$(F=27.7611 ; 3 ; 642 ; p<0.000)$} & \multicolumn{4}{|c|}{$(F=39.2535 ; 3 ; 642 ; p<0.000)$} \\
\hline Constant & $0.035(0.966)$ & & & Constant & $-0.002(-0.069)$ & & \\
\hline SDG 3 & $-0.206\left(-5.43^{* * *}\right)$ & 0.038 & & SDG 6 & $-0.248\left(-7.03^{* * *}\right)$ & 0.05 & \\
\hline Density & $-0.176\left(-4.66^{* * *}\right)$ & 0.037 & & Density & $-0.337\left(-9.56^{* * *}\right)$ & 0.035 & \\
\hline SDG $3 \times$ Density & $-0.023(-0.652)$ & 0.036 & 0.114 & SDG $6 \times$ Density & $-0.095\left(-2.70^{* * *}\right)$ & 0.035 & 0.155 \\
\hline
\end{tabular}

** Significant at 5\%; *** Significant at $1 \%$. 
Table 4 presents the relationship between the SDG variables and the number of deaths from COVID-19. Similar to the previous theoretical model, the interrelationship of the variables had comparable values, with all SDG $3(\beta=-5.43$; $p<0.000)$ and SDG $6(\beta=-7.03 ; p<0.000)$ variables demonstrating a significant negative relationship with the number of deaths from the disease, thus confirming $\mathrm{H}_{2}$ and $\mathrm{H}_{7}$. However, there was a significant improvement in the model resulting from the independent variables, which indicated that the SDGs level better explains the number of deaths caused by the disease than its way of dissemination.

From the analysis of the combined effects, the density was a moderator only in the relationship between SDG 6 and the number of deaths $(\beta=-2.70 ; p<0.000)$. Such an association reveals that the higher population density of a location increases the impact of a lower level of SDG 6 coverage on the number of deaths by COVID-19. Therefore, from these results, only hypothesis $\mathrm{H}_{9}$ was confirmed. Finally, Table 5 summarizes the main results of the theoretical-empirical model of the study.

\section{DISCUSSION}

Confirmation of the hypotheses allows us to infer that the achievement of these SDGs improves the performance of communities throughout the world in the face of a critical health scenario. Hence, an efficient and effective investment in SDGs 3 and 6 is directly associated with the ability of cities, regions or countries to successfully deal with infectious diseases and the resulting death numbers (Khetrapal and Bhatia 2020). To do that, these sustainable goals should not play a secondary role in the current scenario and the post-pandemic future.

Regarding SDG 6, Brazil lacks a greater coverage of water supply (currently it is $83.6 \%$ ) to reach the goal of universal and equitable access to clean water, thus reducing the risk of COVID-19 contagion (SNIS 2018; UN 2020). In addition, there is inequality in access to water when comparing the cities since 149 of them have a service in the range of $60 \%$ to $80 \%$, and in 147 cities, this rate is below 40\% (SNIS 2018).

This difference among regions can be explained by the socio-spatial segmentation and segregation that has historically marked Brazil and is linked to historical, economic, political, cultural and social aspects (Rezende and Heller 2002'; Nahas et al. 2019). In addition, service rates are worse for the sewerage system, whose average in 2018 was $53.2 \%$, with 249 cities with a service range of $20 \%$ to $40 \%$, while 324 had rates below 20\% (SNIS 2018).

Furthermore, several studies (W. Ahmed et al. 2020; Kitajima et al. 2020) show that the poor sanitary and management structure for water distribution leaves cities exposed to the spread of COVID-19. These factors, which are linked to a higher concentration of inhabitants per square kilometer and the reluctance to adopt social distancing policies, have a direct effect on the virus proliferation (Iwaya et al. 2020; Wang et al. 2020). This moderation gets stronger for the SDG levels and the number of deaths from COVID-19 since the closer to the epicenter, the higher is the risk of contamination of water resources due to virus proliferation. In addition, the greater is the population in need of water supply and sanitation, the lower are the rates of compliance with SDGs and the greater are the health risks (Câmara et al. 2020; Wang et al. 2020). Therefore, the literature confirms the hypotheses that refer to SDG 6.

Finally, regarding the performance of Brazilian cities in health management (SDG 3), child mortality has decreased over the period 1990-2015 (initial milestone of Agenda 2030) (França et al. 2017). In addition, in that same period, there was a sharp reduction in the number of cases of communicable diseases, maternal deaths, cardiovascular diseases and chronic respiratory diseases; however, the number of cases of noncommunicable diseases rose across the country (Malta et al. 2017). Furthermore, recent preliminary data from the Ministry of Health (September 2020) indicate a drop in vaccination coverage, which in 2019 reached $72.31 \%$ and currently is at the level of $49.78 \%$ (DATASUS 2020a) ${ }^{2}$. The results may still change since states could report the data until the end of September, but this information preview is disturbing and shows a potential scenario of post-pandemic impacts with an increase in infections of unvaccinated people. In most vaccination campaigns in Brazil, the intended target coverage is between 90\% and 95\% (DATASUS 2020b) ${ }^{3}$. Therefore, from the hypotheses proposed and from previous studies we can infer (Leal Filho et al. 2020; Khetrapal and Bhatia 2020; Iwuoha and Jude-Iwuoha 2020) a relationship between SDG 3 indicators and the COVID-19 statistics, knowing that this disease worsens an already fragile health system.

\section{Table 5. Hypothesis tests for the Theoretical Model}

\begin{tabular}{|c|c|c|c|c|c|}
\hline $\mathrm{H}$ & Structural Paths & B & SE & $P$ & Result \\
\hline $\mathrm{H} 1$ & SDG $3 \rightarrow$ Cases by COVID-19 & -0.224 & 0.04 & $0.000^{* * *}$ & Accepted \\
\hline $\mathrm{H} 2$ & SDG $3 \rightarrow$ Deaths by COVID-19 & -0.206 & 0.03 & $0.000^{* * *}$ & Accepted \\
\hline $\mathrm{H} 3$ & (SDG 3 x Density) $\rightarrow$ Cases by COVID-19 & -0.095 & 0.04 & $0.018^{* *}$ & Accepted \\
\hline $\mathrm{H} 4$ & (SDG $3 \times$ Density) $\rightarrow$ Deaths by COVID-19 & -0.023 & 0.03 & 0.514 & Rejected \\
\hline H5 & (SDG $3 \times$ Distance) $\rightarrow$ Cases by COVID-19 & -1.99 & 0.03 & $0.046^{* *}$ & Accepted \\
\hline H6 & SDG $6 \rightarrow$ Cases by COVID-19 & -0.201 & 0.04 & $0.000^{* * *}$ & Accepted \\
\hline $\mathrm{H7}$ & SDG $6 \rightarrow$ Deaths by COVID-19 & -0.248 & 0.05 & $0.000^{* * *}$ & Accepted \\
\hline $\mathrm{H} 8$ & (SDG 6 × Density) $\rightarrow$ Cases by COVID-19 & -0.138 & 0.04 & $0.000^{* * *}$ & Accepted \\
\hline H9 & (SDG 6 x Density) $\rightarrow$ Deaths by COVID-19 & -0.095 & 0.03 & $0.007^{* * *}$ & Accepted \\
\hline $\mathrm{H} 10$ & (SDG 6 × Distance) $\rightarrow$ Cases by COVID-19 & -3.40 & 0.03 & $0.000^{* * *}$ & Accepted \\
\hline
\end{tabular}

** Significant at 5\%; *** Significant at 1\%.

'Rezende, S. C., and Heller, L. (2002). O saneamento no Brasil: políticas e interfaces [Sanitation in Brazil: Policies and Interfaces]. Belo Horizonte: Editora da UFMG

2 Sistema de Informática do Sistema Único de Saúde [DATASUS]. (2020a). Informações de saúde (TABNET). Available at: http://www2.datasus.gov. br/DATASUS/index.php?area =02 [Accessed 14 Set. 2020].

${ }^{3}$ Sistema de Informática do Sistema Único de Saúde [DATASUS]. (2020b). Cobertura vacinal (TABNET). Available at: http://tabnet.datasus.gov.br/ tabdata/LivrolDB/2edrev/f13.pdf [Accessed 14 Set. 2020]. 


\section{CONCLUSION}

The results show that the investment and dedication to meet the goals established in SDGs 3 and 6 affects cities' performance regarding the COVID-19 statistics since cities that have a better performance in the indicators of these objectives have fewer cases and deaths from COVID-19. Likewise, the population density of the cities and their distance from the pandemic epicenter moderate this relationship.

The pandemic can cause an overload in the health system due to the increase in cases of coronavirus increasing the number of deaths from other diseases not related to COVID-19. Well-being and mental health may also be affected by social isolation. In addition, water is an essential component in combating the transmission of COVID-19 as it is necessary for cleaning the environments and cleaning the body and its uneven management will possibly aggravate the pandemic scenario. Therefore, coping with the COVID-19 pandemic cannot be separated from the goals and indicators outlined in the SDGs since achieving the two objectives analyzed in this research, SDGs 3 and 6, will strengthen the health system, water and sewage management.

As for the contribution of the research, it innovates by establishing a model that can suit other nations for assessing the impact of complying with SDGs on the performance of cities in the battle against COVID-19. The UN report is incisive, showing that world progress so far is below expectations and, with the pandemic, a setback is still expected. Therefore, it is essential to be cautious at this critical moment, bearing in mind that decisions that do not rely on scientific knowledge compromise progress in complying with SDGs and affect the health statistics, especially in developing countries. Finally, in order to contribute to the control of these goals, we emphasize the urgent need for studies addressing the following issues: (1) monitoring compliance of the SDG indicators not addressed in this research and their relationship with COVID-19; (2) evaluation of public policies adopted for achieving these goals; and (3) involvement of the private sector in the search for sustainable growth.

\section{REFERENCES}

Ahmadiara E. (2020). Possibility of Faecal-Oral Transmission of Novel Coronavirus (SARSCoV-2) via Consumption of Contaminated FoSDG of Animal Origin: A Hypothesis. Journal of Food Quality and Hazards Control, 7(1), 2-3, DOI: 10.18502/jfqhc.7.1.2445.

Ahmed F., Ahmed N.E., Pissarides C. and Stiglitz J. (2020). Why inequality could spread COVID-19. The Lancet Public Health, 5(5), e240., DOI: $10.1016 /$ S2468-2667(20)30085-2.

Ahmed W., Angel N., Edson J., Bibby K., Bivins A., O'Brien J.W. ... and Tscharke B. (2020). First confirmed detection of SARS-CoV-2 in untreated wastewater in Australia: A proof of concept for the wastewater surveillance of COVID-19 in the community. Science of the Total Environment, 728, 138764, DOI: 10.1016/j.scitotenv.2020.138764.

Azoulay P. and Jones B. (2020). Beat COVID-19 through innovation. Science, 368(6491), 553, DOI: 10.1126/science.abc5792.

Bobylev S.N., Chereshnya O.Y., Kulmala M., Lappalainen H.K., PetäjäT., Solov'eva S.V.... and Tynkkynen V.P. (2018). Indicators for digitalization of sustainable development goals in PEEX program. Geography, Environment, Sustainability, 11(1), 145-156, DOI: 10.24057/2071-9388-201811-1-145-156.

Câmara S.F., Pinto F.R., Silva F.R. and Gerhard F. (2020). Socioeconomic vulnerability in the face of COVID-19 in municipalities of Ceará Revista de Administração Pública, 54(4), 1037-1051, DOI: 10.1590/0034-761220200133x.

Candido D.S., Claro I.M., de Jesus J.G., de Souza W.M., Moreira F.R.R., Dellicour S. ...and Manuli E.R. (2020). Evolution and epidemic spread of SARS-CoV-2 in Brazil. medRxiv, DOI: 10.1101/2020.06.11.20128249.

Chakraborty, I., and Maity, P. (2020). COVID-19 outbreak: Migration, effects on society, global environment and prevention. Science of the Total Environment, 728, 138882, DOI: 10.1016/j.scitotenv.2020.138882.

Dehning, J., Zierenberg, J., Spitzner, F. P., Wibral, M., Neto, J. P., Wilczek, M., and Priesemann, V. (2020). Inferring change points in the spread of COVID-19 reveals the effectiveness of interventions. Science, 369 (6500), DOI: 10.1126/science.abb9789.

Delanka-Pedige H.M.K., Munasinghe-Arachchige S.P., Abeysiriwardana-Arachchige I.S.A. and Nirmalakhandan N. (2020). Wastewater infrastructure for sustainable cities: assessment based on UN sustainable development goals (SDGs). International Journal of Sustainable Development \& World Ecology, 1-7, DOI: 10.1080/13504509.2020.1795006.

França, E. B., Lansky, S., Rego, M. A. S., Malta, D. C., França, J. S., Teixeira, R., ... and Mooney, M. (2017). Leading causes of child mortality in Brazil, in 1990 and 2015: estimates from the Global Burden of Disease study. Revista Brasileira de Epidemiologia, 20, 46-60, DOI: 10.1590/19805497201700050005.

Hart O.E. and Halden R.U. (2020). Computational analysis of SARS-CoV-2/COVID-19 surveillance by wastewater-based epidemiology locally and globally: Feasibility, economy, opportunities and challenges. Science of Total Environment, 730, 138875, DOI: 10.1016/j. scitotenv.2020.138875.

Huan Y., Liang T., Li H. and Zhang C. (2020). A systematic method for assessing progress of achieving sustainable development goals: A case study of 15 countries. Science of the Total Environment, 725, 141875, DOI: 10.1016/j.scitotenv.2020.141875.

Iwaya G.H., Cardoso J.G., Sousa Jr J.H. and Steil A.V. (2020). Predictors of the intention to maintain social distancing. RAP: Revista Brasileira de Administração Pública, 54(4), DOI: 10.1590/0034-761220200177x.

Iwuoha J.C. and Jude-Iwuoha A.U. (2020). COVID-19: Challenge to SDG and Globalization. Electronic Research Journal of Social Sciences and Humanities, 2(3). Available at : https://ssrn.com/abstract=3670330. [Accessed 12 Set. 2020].

Jurcik T., Jarvis G.E., Zeleskov Doric J., Krasavtseva Y., Yaltonskaya A., Ogiwara K. ... and Grigoryan K. (2020). Adapting mental health services to the COVID-19 pandemic: reflections from professionals in four countries. Counselling Psychology Quarterly, 1-27, DOI: 10.1080/09515070.2020.1785846.

Khetrapal S. and Bhatia R. (2020). Impact of COVID-19 pandemic on health system \& Sustainable Development Goal 3. Indian Journal of Medical Research, 151(5), 395. Available at: http://www.ijmr.org.in/text.asp?2020/151/5/395/285360 [Accessed 10 Set. 2020].

Kitajima M., Ahmed W., Bibby K., Carducci A., Gerba C.P., Hamilton K.A. ... and Rose J. B. (2020). SARS-CoV-2 in wastewater: State of the knowledge and research needs. Science of Total Environment, 739, 139076, DOI: 10.1016/j.scitotenv.2020.139076.

Kristjánsdóttir K.R., Ólafsdóttir R. and Ragnarsdóttir K.V. (2018). Reviewing integrated sustainability indicators for tourism. Journal of Sustainable Tourism, 26(4), 583-599, DOI: 10.1080/09669582.2017.1364741. 
Kruk M.E., Gage A.D., Joseph N.T., Danaei G., García-Saisó S. and Salomon J.A. (2018). Mortality due to low-quality health systems in the universal health coverage era: a systematic analysis of amenable deaths in 137 countries. The Lancet, 392(10160), 2203-2212, DOI: 10.1016/ S0140-6736(18)31668-4.

Leal Filho W., Brandli L.L., Lange Salvia A., Rayman-Bacchus L. and Platje J. (2020). COVID-19 and the UN sustainable development goals: threat to solidarity or an opportunity? Sustainability, 12(13), 5343, DOI: 10.3390/su12135343.

Lucas P.L., Hilderink H.B., Janssen P.H., Samir K.C. van Vuuren D.P. and Niessen L. (2019). Future impacts of environmental factors on achieving the SDG target on child mortality - A synergistic assessment. Global Environmental Change, 57, 101925, DOI: 10.1016/j. gloenvcha.2019.05.009.

MacDonald A., Clarke A., Huang L., Roseland M. and Seitanidi M.M. (2018). Multi-stakeholder partnerships (SDG\# 17) as a means of achieving sustainable communities and cities (SDG\# 11). In: W. Leal Filho, ed., Handbook of sustainability science and research. Cham: Springer, 193-209, DOI: 10.1007/978-3-319-63007-6_12.

Malta D.C., Franca E., Abreu D.M.X., Perillo R.D., Salmen M.C., Teixeira R.A. ... and Naghavi M. (2017). Mortality due to noncommunicable diseases in Brazil, 1990 to 2015, according to estimates from the Global Burden of Disease study. São Paulo Medical Journal, 135(3), 213-221, DOI: 10.1590/1516-3180.2016.0330050117.

Mordeson J.N. and Mathew S. (2020). Sustainable Development Goals: Analysis by the Stakeholder Method. Sustainable Development Goals: Analysis by Mathematics of Uncertainty (pp. 61-105). Cham: Springer, DOI: 10.1007/978-3-030-48523-8_4.

Nahas M.I.P., Moura A.S.A.D., Carvalho R.C.D. and Heller L. (2019). Desigualdade e discriminação no acesso à água e ao esgotamento sanitário na Região Metropolitana de Belo Horizonte, Minas Gerais, Brasil. Cadernos de Saúde Pública, 35(4), e00100818, DOl: 10.1590/0102$311 \times 00100818$.

Rimoldi S.G., Stefani F., Gigantiello A., Polesello S., Comandatore F., Mileto D. ... and Pagani C. (2020). Presence and infectivity of SARSCoV-2 virus in wastewaters and rivers. Science of the Total Environment, 744, 140911, DOI: 10.1016/j.scitotenv.2020.140911.

Rourke M., Eccleston-Turner M., Phelan A. and Gostin L. (2020). Policy opportunities to enhance sharing for pandemic research. Science, 368(6492), 716-718, DOI: 10.1126/science.abb9342.

Sarkar P., Debnath N. and Reang D. (2020). Coupled human-environment system amid COVID-19 crisis: A conceptual model to understand the nexus. Science of the Total Environment, 753, 141757, DOI: 10.1016/j.scitotenv.2020.141757.

Seidman G. (2017). Does SDG 3 have an adequate theory of change for improving health systems performance? Journal of Global Health, 7(1), DOl: 10.7189/jogh.07.010302.

Shakil M.H., Munim Z.H., Tasnia M. and Sarowar S. (2020). COVID-19 and the environment: A critical review and research agenda. Science of the Total Environment, 745, 141022, DOI: 10.1016/j.scitotenv.2020.141022.

Von Braun J., Zamagni S. and Sorondo M.S. (2020). The moment to see the poor. Science, 368(6488), 214, DOI: 10.1126/science.abc2255.

Wang J., Tang K., Feng K. and Lv W. (2020). High temperature and high humidity reduce the transmission of COVID-19, DOI: 10.2139/ ssrn.3551767.

Zambrano-Monserrate M.A., Ruano M.A. and Sanchez-Alcalde L. (2020). Indirect effects of COVID-19 on the environment. Science of the Total Environment, 728, 138813, DOI: 10.1016/j.scitotenv.2020.138813.

Zeng W., Halasa-Rappel Y.A., Baurin N., Coudeville L. and Shepard D.S. (2018). Cost-effectiveness of dengue vaccination in ten endemic countries. Vaccine, 36(3), 413-420, DOI: 10.1016/j.vaccine.2017.11.064.

Zhao Z., Cai M.,Wang F., Winkler J.A., ConnorT., Chung M.G. and Ouyang Z. (2020). Synergies and tradeoffs among Sustainable Development Goals across boundaries in a metacoupled world. Science of the Total Environment, 751, 141749, DOI: 10.1016/j.scitotenv.2020.141749. 